\title{
Mediaciones afectivas en el aula de clases: el afecto como herramienta de significación de los guiones del niño preescolar
}

\author{
Alma Griscel Santiago Cuevas* \\ Asesor: Mtro. Juan Carlos Ayala Perdomo \\ Universidad Autónoma del Estado de México
}

Todo niño en esta escuela, y quiero decir cada uno, tiene el derecho a ser amado. No importa que tan dificil sea, no importa si te vuelve loco desde el mismisimo primer día.

Dales todo el amor y el afecto que puedas.

Peter McLaren

La educación es una de las instituciones básicas de la sociedad humana, tan esencial como lo pueda ser el sistema político o las instituciones económicas. Es tarea de sujetos y su meta es formar también sujetos, no objetos ni mecanismos de precisión: de ahí que venga sellada por un fuerte componente histórico-subjetivo, tanto en quien la imparte como en quien la percibe. Sin embargo, la educación transmite porque quiere conservar ciertos conocimientos, ciertos comportamientos, ciertas habilidades y ciertos ideales que valora positivamente. Nunca es neutral: elige, verifica, presupone, convence, elogia y descarta. Intenta favorecer un tipo de hombre frente a otros, un modelo de ciudadanía, de disposición laboral, etc., que no es el único posible pero que se considera preferible a los demás.

Es así como la sociedad prepara a sus nuevos miembros del modo que le parece más conveniente para su conservación, no para su destrucción. Sin embargo, su búsqueda de conservación no agota el sentido ni el alcance de la educación, porque los aprendizajes humanos nunca están limitados por lo

* Licenciada en Comunicación por la Facultad de Ciencias Políticas y Administración Pública de la Universidad Autónoma del Estado de México. Trabaja en el Museo Universitario "Leopoldo Flores” de la UAEm desde el año 2007. Actualmente, realiza una Maestría en Administración con especialidad en Gestión Organizacional en la misma institución. 
meramente fáctico sino que siempre se ven desbordados, ya que el aprendizaje no se limita a la enseñanza.

El rubro "comunicación y educación" se refiere a un territorio conformado por dos disciplinas afines, entre las cuales hay varias formas de vinculación posible. Tradicionalmente, los estudios cualitativos en el campo de la comunicación, con respecto a la educación, han consistido en estudiar la función de los medios masivos en cuanto a agentes de educación no formal e informal, la problemática que representa la inclusión de las nuevas tecnologías en el aula de clases y fuera de ella, así como la educación para una lectura crítica de los medios de comunicación.

Sin embargo, se ha dejado de lado, en los estudios cualitativos desde el campo de la comunicación, la educación vista como un proceso de comunicación, un proceso de relación fundamentalmente con los otros; esa comunicación interpersonal, frente a frente, que se da en el aula de clases y que no puede ser sustituida por los más sofisticados avances tecnológicos es de interés para esta investigación.

Desde la comunicación, el objeto de estudio es el sujeto mismo que se encuentra en el aula de clases y que interactúa constantemente con los otros: el docente y sus compañeros; es un sujeto lleno de emociones, sentimientos, valores e ideologías, que no han sido aprendidas en el espacio escolar, sino que son resultado de su interacción con la sociedad que lo rodea, y que hace que llegue al Jardín de Niños cargado de elementos que lo hacen ser él o ella, desde una realidad diferente a la de los demás, y por ende percibir una realidad, aparentemente la misma, diferente a la que otros perciben.

El significado de los mensajes escolares es negociado por los sujetos receptores (educadores y educandos), dado que ningún significado es unívoco, sino más bien polisémico (esto sin embargo, no exonera al significado preferente) y también porque los significados no siempre son apropiados según han sido propuestos, puesto que el proceso de la comunicación no concluye con la transmisión del mensaje, sino que más bien inicia.

La postura de esta investigación se basa en la idea de que el emisor y el receptor son sujetos situados socioculturalmente, y es su propia adscripción sociocultural la que determina tanto el tipo de mensajes como su apropiación, misma que no es resultado automático a la exposición a los mensajes, sino el producto resultante de diversas mediaciones, en cuyo proceso interactúan distintas instituciones sociales en las que el receptor participa simultáneamente y por tanto es sujeto de su influencia. Reconocer la red de mediaciones en la 
apropiación de mensajes que se da en la relación niño-iguales-educadora implica buscar una explicación basada en una "causalidad múltiple".

En este contexto podría afirmarse que los sentidos y significados últimos de los mensajes escolares son producto de las mediaciones y que una articulación distinta de ellas llevaría a una producción alternativa de significados. De aquí el indagar las mediaciones en este trabajo.

Conceptualmente es importante asumir que la recepción es un proceso complejo y mediado que antecede y prosigue al mero momento de estar en el aula de clases, es decir, se entreteje con la vida cotidiana debido a que se desarrolla en distintos escenarios en los que intervienen distintos agentes e instituciones sociales. El proceso de la recepción de ninguna manera es unívoco, directo ni transparente, sino por el contrario complejo y hasta contradictorio, mediatizado por distintos elementos situacionales, institucionales, culturales, económicos, políticos, etc. Entender así la comunicación, hace importante ver los contextos en los que se están dando las relaciones y no sólo las relaciones mismas. En buena medida abordar este proceso es entender la interacción de las distintas instituciones sociales en las que participan los receptores (educandos preescolares) y que construyen conjuntamente el aprendizaje social (guiones) del niño.

$\mathrm{Al}$ investigar las mediaciones afectivas, más que contar con un análisis exhaustivo de todos los elementos que intervienen en el proceso de recepción al interior del aula de clases, se busca explorar una opción para crear condiciones que permitan encontrar o imaginar, en el trabajo cotidiano, esas "claves" de razón práctica que ayuden a cumplir la práctica educativa desde una perspectiva democrática, basada en el diálogo y participación de cada miembro del grupo escolar.

Se seleccionaron y analizaron, con metodología etnográfica, una serie de incidentes concretos y representativos, no de lo que debería suceder, sino de lo que sucede en un aula de clases preescolar. La metodología descrita es exploratoria, en el sentido de que no tiene hipótesis específicas para ser verificadas, sino que busca generarlas. El objetivo, era situarse en el contexto real de la cotidianidad del aula de clases utilizando la postura teórico-metodológica de las multimediaciones de Guillermo Orozco. Los agentes teóricos, están orientados a la búsqueda de cómo los educandos, en edad preescolar, mediatizan afectivamente la significación de sus guiones. La finalidad no es contar con un cúmulo de datos, sino que exista relevancia explicativa en el área de comunicación y educación, que atraiga la atención de agentes relacionados con la educación y la comunicación hacia las condiciones de recepción de los estudiantes en des- 
ventaja, los faltos de afecto, aquellos que encuentran en la escuela un espacio de bienestar emocional cuando carecen de él en el interior de su familia.

Con base en los trabajos sobre recepción televisiva de Orozco, que rechazan que el nińo sea un receptor pasivo, se realizó un marco conceptual acerca de cómo aprende el niño preescolar, integrando perspectivas de la teoría del desarrollo cognoscitivo y la teoría del aprendizaje social; llegando a la conclusión de que el niño preescolar es un aprendiz social cognoscitivamente activo.

Es necesario aclarar en este punto que Guillermo Orozco, no utiliza propiamente el término "Mediaciones Afectivas" -en su Postura Teórica Metodológica, éstas se incluyen dentro de las Mediaciones Cognoscitivas bajo el nombre de valoración afectiva-, sin embargo, el cuerpo teórico de sus investigaciones sobre recepción fue empleado para desarrollar este concepto.

Bajo la denominación de "Mediaciones Afectivas", se agrupan una serie de prácticas afectivas concretas -entendiendo el afecto como una forma de ayuda- que fungen como herramientas de significación de los guiones del niño preescolar. Dichas prácticas nos llevan a una transformación de la interacción significativa entre individuos y grupos en la construcción de sentido a través de los procesos comunicativos, al influir en la forma de autoidentificarse y de identificar la propia posición en el aula de clases.

Para poder comprender el sentido de las transformaciones actuales y potenciales que se dan en las escuelas de educación básica del país, es imprescindible profundizar en el análisis de la cotidianidad escolar. Es necesario seguir investigando lo que significa para los niños mexicanos su paso por las escuelas públicas, así como lo que importa en la vida y la conciencia de los profesores el contexto institucional de su trabajo.

Esto es, rescatar el papel de acción del receptor con respecto a su medio, transformándolo, comprendiéndolo y asimilándolo, sin por ello "magnificar" la individualidad dentro de lo social, sino comprendiendo que sus formas de aprendizaje e interpretación del medio dependen de los guiones que han construido, que construyen y significan a partir de la interacción con otros sujetos. 